WellBeing International

WBI Studies Repository

1986

\title{
The Case Against Intensive Farming of Food Animals
}

Linda D. Mickley

The Institute for the Study of Animal Problems

Michael W. Fox

The Humane Society of the United States

Follow this and additional works at: https://www.wellbeingintlstudiesrepository.org/acwp_faafp

Part of the Agribusiness Commons, Animal Studies Commons, and the Business Law, Public Responsibility, and Ethics Commons

\section{Recommended Citation}

Mickley, L.D., \& Fox, M.W. (1986). The case against intensive farming of food animals. In M.W. Fox \& L.D. Mickley (Eds.), Advances in animal welfare science 1986/87 (pp. 257-272). Washington, DC: The Humane Society of the United States.

This material is brought to you for free and open access by WellBeing International. It has been accepted for inclusion by an authorized administrator of the WBI Studies Repository. For more information, please contact wbisr-info@wellbeingintl.org.

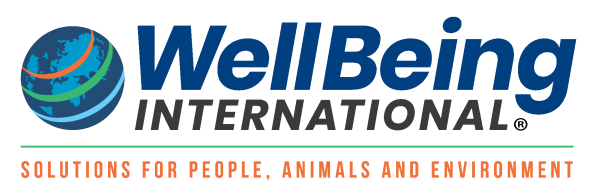




\title{
THE CASE AGAINST INTENSIVE FARMING OF FOOD ANIMALS
}

\author{
Linda D. Mickley ${ }^{2}$ and Michael W. Fox ${ }^{3}$
}

\section{Overview}

Intensive poultry and livestock husbandry practices, which developed in the United States shortly after World War II, are part of the "revolution" in American agriculture. This revolution, however, is not leading to the flourishing of American farming, but to its demise. Our once labor-intensive food-production system has become increasingly capital intensive, and dependent upon machinery, automation, and petrochemical-based fertilizers and pesticides. This now over-capitalized industrialization of agriculture has reaped enormous profits (for a few), and agricultural economists are quick to point out that not only do Americans pay proportionally less for their food than any other country, our farms also help feed a hungry world. Yet, there are many hidden costs, costs not directly reflected by or computed into the price of our food.

The sociological and economic costs of the U.S. agricultural system are evident in such problems as rural unemployment, bankruptcy of family farms, and chronic overproduction of commodities such as milk, that are buoyed up by price support programs. The large-scale operations or "super" farms are benefitted by capital-intensive buildings, automation, and drugs and feed additives, as well as the economies of scale, while small- to medium-sized farmers must borrow against their land, crops, or animal products. Such inequities are further compounded by tax structures that favor large farms.

The ecological cost is measured in terms of irreparable damage to our farmlands due to soil erosion, depletion of trace minerals, soil humus, and deep water aquifer reserves, along with pesticide and chemical fertilizer pollution of ground waters. Such are the consequences of imposing an inappropriate technology and industrial paradigm upon the delicate biological balance of agriculture.

This same paradigm has been applied to farm animals in the industrial-scale production of meat, eggs, and dairy products. Such application is changing animal busbandry into animal technology wherein the health and well-being of the animals, like the health and well-being of the land, are sacrificed in the name of efficiency and productivity. The enhancement of efficiency and productivity of farm animals is achieved through the feeding of high-energy, 
low-fiber feedstuffs (such as corn, soy, and food industry by-products), selective breeding for rapid growth and weight gain, and housing in varying degrees of confinement.

The feeding of high-energy, low-fiber diets has been linked to metabolic and production-related diseases such as ketosis and laminitis in dairy cattle (Webster 1986; Harvey 1983; Fox 1983; Van den Bergh 1976), and the rumenitisliver abscess complex in beef cattle (Fox 1984). Farm animals are also harmed by being fed crops and by-products that are contaminated with residual pesticides and other hazardous chemicals such as drugs (Long 1985; Peterson 1986; Somogyi 1985), and which are nutritionally deficient as well (a problem in part attributable to depletion of trace minerals in the soil). Improper nutrition is one of the factors that contributes to the suffering of intensively-housed farm animals, which, like the improper use of nutrient fertilizers, is linked with poor viability and higher pest susceptibility of crops (Chaboussou 1980).

Humans have long exercised control over animals and plants by means of selective breeding. In the case of farm animals, however, selective breeding for rapid growth (e.g., broiler chickens and hogs) and high productivity (e.g., laying hens and dairy cows) contributes to a host of production-related ("domestigenic") diseases and/or increases in susceptibility to infection (Siegel 1983; Fox 1984). The term "agricologenic" is applicable to those unintentional or undesirable side effects of crop production systems, such as greater susceptibility to disease and pests due to selection for greater productivity in various hybrid strains (Hodges and Scofield 1983). Selective breeding alone of crops for high yield does not guarantee such such yields, as it has been noted that U.S. crops produce, on the average, only $20-25 \%$ of their genetic potential, and are prevented from reaching that potential by adverse physical (abiotic) environments, diseases, arthropod pests, nematodes, and weeds (Cook 1986).

Confinement housing, especially in the case of veal calves, poultry, and hogs, is the third tool used by modern U.S. agriculture to increase animals efficiency and productivity. It is often stated by agribusiness advocates that animals in intensive housing would not produce if their well-being and health were truly compromised. This belief is only a half-truth: In reality, productivity (or performance) is not an absolute guarantor of welfare (Fox 1984). While few farmers are deliberately cruel, the economic treadmill on which modern farmers find themselves forces them to increase stocking density, which in turn forces them to jeopardize or ignore individual animal welfare in order to maximize overall production (Fox 1984).

Such increases are justified by the confinement unit producers, as they purportedly allow for greater productivity per unit of building space. These producers may also argue that less heat must be supplied to the units due to body heat generated by the animals, and therefore stock requires less feed in colder months.

This latter reason for overstocking is not legitimate; it is false economy at best, as the animals will suffer heat stress in the summer, and the negative 
effects of high relative humidity and noxious fumes from excreta if ventilation is inadequate.

In addition, animals in overcrowded, restrictive environments may develop learned helplessness as a result of their having no control over or escape from their immediate environments. It is theorized that learned helplessness leads to immunosuppression, reduced stress resistance, and increased disease susceptibility (Dantzer and Mormède 1983; Fox 1984). It must be reiterated that in spite of these known problems that affect animals' productivity, it has not been cost-effective to rectify them. It is more expedient instead to treat the symptoms with drugs. An analogous situation exists in the use of pesticides on crops.

These nutritional and genetic factors, in combination with environmental influences, account for the etiological bases of most of the complex multifactor diseases and attendant suffering of farm animals. It is simplistic thinking to blame viruses, bacteria, and other pathogens solely for the infectious diseases that afflict farm animals. The presence and abundance of pathogens (as also occur in monocultures of corn, oranges, and other crops) are symptoms of improper husbandry and a consequence, in part, of selective breeding and feeding for high productivity. Hence, the over-reliance today on pesticides in crop production and on vaccines, antibiotics, and other drugs in livestock and poultry production, is an over-reliance that profits neither the farmer nor the consumer - and can harm both (see figure 1).

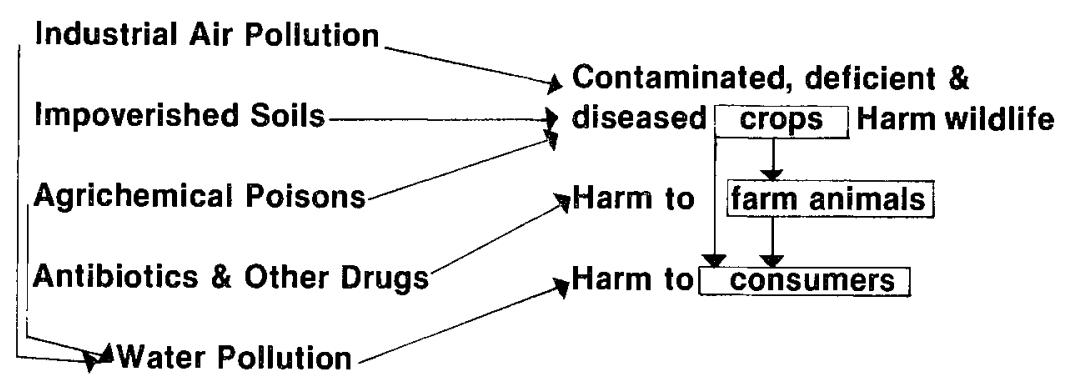

Figure 1. Multi-factor scenario of farm animal health problems.

The ultimate high technology corrective-genetic engineering - is the next capital-intensive and monopolistic innovation of agribusiness that has been shown to favor large and super farms (OTA 1985). Monsanto's geneticallyengineered bovine growth hormone and herbicide- and pesticide-resistant seeds herald the next agricultural revolution. The future also holds the possibility of transgenic animals - pigs endowed with the genes of cattle, 
for example. All these newly engineered life-forms are patentable, and as Doyle (1985) has shown, may well lead to global corporate monopoly of germ plasm and of agricultural practices. A paradigm shift in agricultural and farm animal husbandry practices is imperative, lest genetic engineering result in adverse impacts on the environment and farm animal welfare and health, resulting in this new technology becoming a Pandora's box rather than a cornucopia.

It is perhaps too simplistic and judgmental to conclude that the many domestigenic diseases that afflict farm animals arise because the animals are treated like unfeeling production machines. What has taken place, in essence, is a substitution of empathetic and compassionate husbandry by animal management techniques designed to maximize the overall productive efficiency of the entire system, rather than optimizing the production, health, and well-being of animals on an individual basis. In other words, the ethical principles of humane husbandry have become subordinate to two higher values: first, the economic imperative of maximizing profit margins, (which is essential considering the high capital investment of confinement systems for veal, poultry, and hogs); and second, the subordination of ethics to the ideology of industrialized efficiency. Animals have come to be regarded as simply the living parts of the "factory" that is modern farming.

The well-being of American agriculture is indeed a complex subject, fraught with interrelationships, predictions, recriminations, and at times, high emotionalism. In this paper, we will be concentrating on several aspects of the entire picture that we feel are fundamental to the issue of animal welfare in modern agriculture. First, we will take a brief look at two farm animal species maintained in very restrictive systems, that is, battery-caged laying hens and tethered and/or crated brood sows.

Next, the human costs in terms of occupational diseases and consumer health hazards will be considered. Finally, some humane alternatives to the factory systems for these species will be presented.

\section{Battery-Cage Laying Hens}

It is estimated that there were 280 million hens and pullets of laying age in the United States in 1982 (USDA 1983). Of these numbers, upwards of 95\% are housed in restrictive wire battery cages for the major portion of their lives (Fox 1984). While such intensive systems do indeed eliminate certain stressors (e.g., predators, some climatic extremes, and parasites), one must undoubtedly question the humaneness of systems in which cannibalism, feather and vent picking, and stereotypic pacing are common occurrences (Fox 1984; Sambraus 1985). The production-related behavioral problems seen in laying hens (table 1) are perhaps better understood when one considers that chickens evolved from ancestors who built nests, were secretive in their laying habits, and lived in small, male-dominated flocks (Kilgour 1985).

The two parameters of the battery system, cage size and design and stocking density, are to be held accountable for the production-related behavioral and 
Table 1. Behavior or husbandry problems in poultry.

\begin{tabular}{|c|c|c|}
\hline $\begin{array}{l}\text { Behavior or } \\
\text { husbandry problem }\end{array}$ & Possible cause(s) & References ${ }^{1}$ \\
\hline disease & social stress & 1 \\
\hline hysteria & monotonous environment & 2,3 \\
\hline $\begin{array}{l}\text { head ticks, } \\
\text { head-flicking, } \\
\text { and hyperactivity }\end{array}$ & confinement & 4 \\
\hline cannibalism & $\begin{array}{l}\text { nutritional deficiency } \\
\text { (arginine), overcrowding }\end{array}$ & $5,6,7,8$ \\
\hline $\begin{array}{l}\text { feather pecking } \\
\text { (picking) }\end{array}$ & $\begin{array}{l}\text { dietary imbalance } \\
\text { (methionine deficiency) } \\
\text { and overcrowding, socially } \\
\text { facilitated "vice," lack of } \\
\text { fiber, eating diet too fast, } \\
\text { boredom }\end{array}$ & $5,6,7,8$ \\
\hline pick-out & $\begin{array}{l}\text { associated with cloacal } \\
\text { prolapse in battery layers, } \\
\text { possibly "vice" or related } \\
\text { to overcrowding }\end{array}$ & $\begin{array}{l}8, \text { personal } \\
\text { observation } \\
\text { (M.W. Fox) }\end{array}$ \\
\hline $\begin{array}{l}\text { pre-laying } \\
\text { pacing }\end{array}$ & $\begin{array}{l}\text { lack of adequate stimuli } \\
\text { or site for nesting }\end{array}$ & $3,9,10$ \\
\hline $\begin{array}{l}\text { self- } \\
\text { multilation }\end{array}$ & $\begin{array}{l}\text { visual isolation } \\
\text { from other birds }\end{array}$ & 8,11 \\
\hline $\begin{array}{l}\text { redirected } \\
\text { aggression and } \\
\text { stereotyped } \\
\text { behavior }\end{array}$ & $\begin{array}{l}\text { crowding stress, feeding } \\
\text { frustration }\end{array}$ & 12,13 \\
\hline $\begin{array}{l}\text { aggression and } \\
\text { social stress }\end{array}$ & $\begin{array}{l}\text { overcrowding, unstable } \\
\text { grouping }\end{array}$ & 14 \\
\hline egg-eating & boredom & 8 \\
\hline $\begin{array}{l}\text { tonic } \\
\text { immobility }\end{array}$ & $\begin{array}{l}\text { fear response to } \\
\text { novel situations }\end{array}$ & 3 \\
\hline
\end{tabular}

${ }^{1}$ Data obtained from: 1) Gross 1976; 2) Ferguson 1968; 3) Craig and Adams 1984; 4) Levy 1944; 5) Allen and Perry 1975; 6) Duncan and Hughes 1974; 7) Ewbank 1969; 8) Sambraus 1985; 9) Bareham 1975; 10) Mills and Wood-Gush 1985; 11) Wood-Gush 1973; 12) Duncan and Wood-Gush 1972; 13) McBride 1966; 14) McBride 1968.

physical maladies of the laying hen. The size of the cage $(25 \times 38 \mathrm{~cm}$ or $38 \times$ $51 \mathrm{~cm}$ ), coupled with stocking density (three to five birds per cage), denies the bird of the chance to perform many of its "natural" movements, such as wing flapping and stretching, dust bathing, ground scratching; movements that undoubtedly have an important place in the behavioral repertoire of the laying hen (Fox 1984). Frustration of pre-laying activities, such as distancing 
from the flock and nest building, also occurs in the barren battery cages, and manifests itself in the form of stereotypic pacing. The incidence of stereotypic pacing should be considered indicative of frustration from the welfare viewpoint, and is undesirable for the following economic reasons as well: 1) considerable energy is expended, and this may in turn reflect an increase in feed consumption; 2) there is an increased risk that birds will suffer feather loss, skin abrasions, or even death from trapping while pacing; and 3) some birds will actually lay while pacing, resulting in broken eggs (Mills et al. 1985)

Important research has been conducted in an effort to more fully understand the needs of the laying hen and how fulfillment of such needs can be met in modern systems. Gross and Siegel (1982), for example, discovered that chicks that were habituated (socialized) to humans had more than a $60 \%$ reduction in the occurrence of death and pericarditis compared to ignored birds. Perhaps even more exciting, these researchers found that socialized birds had improved feed efficiency, increased antibody response to both Mycoplasma gallisepticum and Escherichia coli, and increased resistance to the effects of environmental stresses. In reality, Gross and Siegel may have quantitatively proved what all good animal caretakers know-- that tender, loving care pays off. Tauson (1984) enriched the caged hen's environment with the addition of a perch, and found that it is possible to get the same number of eggs in cages with perches as in the standard cage at the same stocking density used in Sweden at the time of his study $\left(480 \mathrm{~cm}^{2}\right.$ cage floor area). The Gleadthorpe or "get-away" battery cage does provide means for the hens to meet some of their behavioral needs, with the provision of a nest box, and separate feeding area (Fox 1984). Reductions in aggression, feather picking, foot problems, nervousness, and stereotypic behaviors were noted in this system, as was an increase in production over the standard battery cage (Fox 1984). The use of the shallow cage has been extensively reviewed by Hughes (1983) in terms of productivity, mortality, and feed efficiency. Hughes pointed out that while some benefits did indeed occur with the use of these cages, such improvements should not distract from the crucial issue of total space requirements of the hens, "by merely providing more space for one particular, albeit, important, activity."

Total space required by hens is probably the single most important parameter of welfare in the issue of the laying hen. In the United States and much of Europe, living space for these animals is in the range of $230-300 \mathrm{~cm}^{2}$ (Fox 1984). Yet, a West German study (Bogner et al. 1979) determined that a hen requires $538 \mathrm{~cm}^{2}$ to perform a restricted wing stretch, $528 \mathrm{~cm}^{2}$ to body stretch, $506 \mathrm{~cm}^{2}$ to preen, $497 \mathrm{~cm}^{2}$ just to ruffle its feathers, and $424 \mathrm{~cm}^{2}$ when resting. In September, 1985, the United Kingdom government-appointed Farm Animal Welfare Council (FAWC) released its assessment of the laying hen systems currently in use in the European Economic Community (EEC). The FAWC states that it does not approve of either the battery-cage system nor the wire- or slatted-floor loose houses where no litter is provided. Bearing 
the above space requirements and the FAWC decision in mind, it is difficult to fathom the reasoning behind the decision by the E.E.C. Council of Ministers to set the minimum cage size at $450 \mathrm{~cm}^{2}$ per bird. The reasons are undoubtedly political, and undoubtedly the hens will continue to suffer in E.E.C. countries until that time when sufficient pressure can be brought to bear on the Council to set a date for the phasing out of battery cages in those countries (Agscene 1985, 1986). All countries would do well to follow the enlightened example set by Switzerland, which has outlawed the battery cage. All Swiss egg producers must provide their hens with comfortable compartmentalized housing by 1990 (New Scientist 1986). Swiss researchers (Huber et al. 1985) have already begun work on determining the hens' preferences in nesting materials.

\section{Tethered and/or Confined Brood Sows}

Intensive livestock husbandry systems attempt to maximize production as a response to upwardly spiraling costs for stock, feed, equipment, medication, and labor. One way in which hog producers are attempting to maximize production is by restraining brood (gestating) sows in narrow stalls, either for just farrowing, or for both gestation and farrowing. Although this paper will concentrate on the concerns raised about the tethering of sows, the confinement of sows to narrow crates that offer no room in which to turn around present many problems similar to those encountered in tether systems. Injuries, obesity, stereotypic behavior (Fox 1984), and lowered prefarrowing sow weights and reduced farrowing rates have been reported (Pig America 1984). It is estimated that there were 10 million sows farrowing in 1982 (USDA 1983), and if even a conservative estimate of $1 \%$ of the total $(100,000)$ are tethered sows, and 510\% $(500,000$ to one million) are confined to gestation crates, surely such numbers dictate that welfare of the brood sow be addressed.

Tether stalls are usually narrow, devoid of bedding, and concrete slatfloored, with the animals tied either to the floor or to the front of their crates by a short tether attached to a neck- or shoulder-collar or girth harness. This method of restraint appeals to the modern producer for the following reasons: 1) low investment, 2) minimum use of floor space and equipment, and 3) ease of maintenance and monitoring of animals (Becker et al. 1985). Although the foregoing reasons may make sense from a purely technocratic viewpoint, the tethering of sows must be analyzed primarily from an animal welfare viewpoint. The pig is one of the most intelligent domestic animals, with a highly developed repertoire of social and exploratory behaviors, yet it has been subjected to some of the most intensive systems of animal agriculture (Kilgour 1985). The tethering of brood sows should be considered to be particularly deprivational to the animals, as close confinement in a gestation stall, with subsequent placement into a farrowing crate, will often condemn the sow to severe restriction for her entire reproductive life. 
In recent years, many scientific studies have been conducted in an attempt to determine if sow welfare is indeed compromised in tether systems (see, e.g., Becker et al. 1985; Barnett et al. 1985; Cronin 1985; Gustafsson 1983; Ekesbo 1981; and Vestergaard 1981). An evaluation of welfare of tethered sows necessarily includes investigation of such factors as the physiological indicators of stress, production parameters such as breeding rate and piglet mortality, and incidence of stereotypic behavior.

Pbysiological Indicators of Stress. - As noted by Dantzer and Mormède (1981), exposure to physical or psychological stressors elicits a wide range of physiological changes in the organism that can be more or less easily detected. One such change important in the evaluation of stress in pigs is the change in levels of serum corticosteroids; animals exhibiting higher than normal plasm corticosteroid levels are claimed to be in a state of stress (Dantzer and Mormède 1981; Moss 1981). Two recent studies strongly suggest that gilts kept in tether systems develop chronic stress response. Barnett et al. (1985) demonstrated that pregnant gilts kept in tethers showed a $76-82 \%$ increase in corticosteroid levels "at rest" over other systems $(2.2 \mathrm{ng} / \mathrm{ml}$ for tethered gilts vs. $1.4 \mathrm{ng} / \mathrm{ml}$ for those housed in stalls and indoor or paddock groups). Becker et al. (1985) found that at the end of four weeks' tethering, gilts exhibited higher concentrations of serum cortisol in the morning. The authors suggest that because morning is a time of greater activity for swine, the physical restrictions imposed upon them by tethering may account for this higher concentration. It is also suggested that such restriction may induce chronic stress response in these animals (Becker et al. 1985).

Production-Related Problems. - Reports of such problems as sow illness at farrowing (Ekesbo 1981), increased piglet mortality (Gustafsson 1983), and lower mating rates and irregular estrus (Becker et al. 1985) indicate that the keeping of brood sows in tethers or stalls is, in fact, counter-productive to the maximization of production.

Vestergaard (1983/84) reports that tethering during pregnancy and/or farrowing-lactation resulted in an increased duration of farrowing itself, and that tethered sows showed much restlessness in the last 24 hours prior to giving birth; he interpreted this restlessness as thwarted nesting behavior Modern producers often respond to longer farrowing times by administering prostaglandin, which induces labor. As this hormone drastically increases the nest-building motivation, sows restricted in a narrow farrowing crate may be extremely stressed (Fox 1984), and perhaps even more so if tethered as well. A synopsis of behavioral, health, and husbandry problems documented in confined sows is presented in table 2.

Stereotypies. - Although stereotypies as related to welfare have been reported in tethered sows in previous studies (see table 2), Cronin (1985) has presented a comprehensive look at these behaviors. One study was designed to describe the development of stereotypies in sows after tethering (see Cronin 1985, chapter 3). The authors concluded that environmental directed stereotypies (directed towards chains, drinkers, bars, etc.) develop as 
Table 2. Behavior, health, and husbandry problems in tethered or confined sows. ${ }^{1}$

\begin{tabular}{|c|c|c|}
\hline $\begin{array}{l}\text { Behavior, health, or } \\
\text { husbandry problem }\end{array}$ & $\begin{array}{l}\text { Possible } \\
\text { cause(s) }\end{array}$ & References $^{2}$ \\
\hline $\begin{array}{l}\text { traumatic } \\
\text { or physical injuries }\end{array}$ & $\begin{array}{l}\text { poorly designed } \\
\text { crates and/or flooring, } \\
\text { residual urine and dung }\end{array}$ & 1,2 \\
\hline $\begin{array}{l}\text { infertility or } \\
\text { low fecundity }\end{array}$ & $\begin{array}{l}\text { social isolation/ } \\
\text { confinement }\end{array}$ & $3,4,5,11$ \\
\hline $\begin{array}{l}\text { oral stereotypies: } \\
\text { mouthing, champing, } \\
\text { polydipsia, vacuum } \\
\text { chewing, bar-biting }\end{array}$ & $\begin{array}{l}\text { boredom, lack of } \\
\text { bedding, feed-directed } \\
\text { activity, low-bulk feed }\end{array}$ & $\begin{array}{l}1,6,7,8 \\
9,10,11 \\
12,13\end{array}$ \\
\hline arteriosclerosis & social isolation & 8 \\
\hline subclinical disease & close confinement & 1 \\
\hline "mourning behavior" & $\begin{array}{l}\text { boredom, lack of } \\
\text { bedding }\end{array}$ & $9,11,14$ \\
\hline $\begin{array}{l}\text { increased farrowing } \\
\text { time, complications } \\
\text { at farrowing }\end{array}$ & $\begin{array}{l}\text { lack of exercise } \\
\text { due to confinement }\end{array}$ & $1,2,12,15$ \\
\hline $\begin{array}{l}\text { increased piglet } \\
\text { mortality }\end{array}$ & $\begin{array}{l}\text { fetal development } \\
\text { and farrowing illness } \\
\text { due to confinement }\end{array}$ & 1,2 \\
\hline lameness & $\begin{array}{l}\text { lack of wear on toes } \\
\text { due to flooring }\end{array}$ & 12 \\
\hline
\end{tabular}

${ }^{1}$ Confined in this context refers to farrowing and/or gestation crates.

${ }^{2}$ Data obtained from: 1) Ekesbo 1981; 2) Gustafsson 1983; 3) Kiley-Worthington 1977; 4) Becker et al. 1985; 5) Fox 1984; 6) Fraser 1974; 7) Ewbank 1969; 8) Fraser 1975; 9) Vestergaard 1981 ; 10) Sambraus 1985 ; 11) Cronin 1985; 12) Barnett et al. 1985; 13) Rushen 1985; 14) Hall 1984; 15) Vestergaard 1983/84.

a result of frustration/conflict at being restrained, and the sows' consequent loss of control over their environment.

A study was also formulated to test the hypothesis that endorphins (endogenous opiates) play a role in the development and performance of stereotypies by tethered sows (see Cronin 1985, chapter 4). Tethered sows were treated with the specific opiate antagonist, naloxone, while performing stereotypies. While saline injections did not effect the behaviors of the sows, naloxone caused severe disruption of the stereotypies, but not of the normal behaviors of the sows. Cronin summarized these results as follows:

The results strongly suggest that endorphins may be the factor underlying the development and performance of stereotypies. Endorphins are released in response to stress, and in time, sows may learn to self-stimulate the release 
through the performance of stereotypies. Stereotypies probably function to reduce the perception of the negative aspects of the real environment, over which tethered sows have no control, and "rebuild" a new and possibly much reduced environment that they control through the performance of stereotypies. The results suggest that sows perceive tethering in a very negative way. (p. 140)

It was also suggested by Cronin that stereotypies have direct influences on sow productivity. Many tethered sows become highly active through stereotypy performance (even though they are unable to locomote), and these animals have a higher metabolic rate and poorer feed conversion efficiency/growth than less active sows. Such activity may contribute to the "thin sow" syndrome. Cronin points out that not all sows can adequately cope with the stress of being tethered; such animals are more likely to be culled at an early age as poor producers. To sum these observations, Cronin states:

Stereotypies are indicators of a poor environment and thus lower welfare status. It should be the aim of all pig producers therefore, to achieve better welfare for their animals. Better welfare will undoubtedly result in higher profits, but also in reduced public displeasure at the current intensive husbandry systems which disregard the welfare of the sows. (p. 135)

In a positive move for the welfare of dry sows, the Standing Committee of the European Convention for the Protection of Animals Kept for Farming Purposes is considering draft recommendations concerning pigs. The Farm Livestock Specialist Group of the Scientific Advisory Panel, World Society for the Protection of Animals, has submitted the following:

That the confinement of dry sows to individual stalls, with or without tethering, is a serious welfare problem, inevitably leading to severe restrictions on the animal's freedom of movement thus denying normal exercise that can give rise to patterns of abnormal behaviour and commonly causes injuries and leg weakness (WSPA 1985).

It is to be hoped that this statement will be taken under serious consideration and a precedent thereby set for the humane treatment of sows.

\section{Occupational and Consumer Health Hazards}

Although the American public generally envisions the farmer as working out-of-doors, breathing fresh air, and being subjected to few of the stresses endured by his urban and suburban neighbors, nothing could be further from the truth for the majority of the farmers engaged in intensive animal agriculture. Today's animal farmers are exposed to toxic fumes from the herbicides and pesticides used on the crops, noxious dust from on-farm grain storage centers, poisonous gases from the animal confinement units, and physical danger from the powerful, high-speed equipment. It has been 
reported that 200,000 disabling injuries and 2,000 annual accidental deaths befall farmers; they share the three highest rates for "industrial accidents" with miners and construction workers (Houston Post 1984). It has been estimated that up to one million American farmers may now work in livestock confinement buildings alone, and as many as $70 \%$ of Iowan farmers may have respiratory difficulty at any given time (Donham et al. 1984).

In a study of swine confinement units, Clark et al. (1983) found levels of carbon monoxide, carbon dioxide, ammonia, and hydrogen sulfide to be in excess of threshold limit values for occupational exposure. The same study reported that airborne concentrations of total and gram negative bacteria in poultry and swine units were as high or higher than those found in wastewater treatment plants, solid waste/sludge composting plants and cotton card rooms where microbiologically contaminated organic dusts were also present. Judging from the ramifications of being housed in such conditions, it is little wonder then that modern farmers feel it necessary to maintain their intensively housed stock on subtherapeutic levels of antibiotics, and on growth promotants such as hormones.

Such drugs constitute the second health hazard, that of consumer risk from eating animal products from factory-farmed livestock. There are several recent developments implicating that intensive animal agriculture may jeopardize consumer health. Consider that of the nearly 30 million pounds of antibiotics produced annually on the United States, one-half of them are fed to farm animals, and that the Food and Drug Administration estimates that $80 \%$ of swine, $60 \%$ of cattle, and $30 \%$ of chickens are fed antibiotic-laced feeds (Allman 1984). The sobering aspect of these facts is that animals reared for consumption are often fed the same antibiotics (i.e., tetracycline and penicillin) in subtherapeutic doses that are used to treat bacterial infections in humans. It is now known that microorganisms can become resistant to these drugs (Holmberg et al. 1984; Dixon 1986), and that such resistance can be transferred between microbes (O'Brien et al. 1984). The implications of these findings is that subtherapeutic dosing of farm animals may effectively select for organisms resistant to the antibiotics. The use of antibiotics to combat stressful and crowded environmental conditions may well be considered an irresponsible and/or dangerous practice; one that renders tetracycline and penicillin useless against human illness. Unfortunately, in November, 1985, the U.S. Department of Health and Human Services chose to ignore these implications and refused to ban the use of these two drugs in animal feeds (Rhien and Siwolop 1986)

It is interesting to note that while livestock usage of drugs and feed additives amounted to a $\$ 2$ billion a year expenditure for producers, veterinary care for these animals was disproportionately low, as shown in table 3 (Rheines and Siwolop 1986; Charles and Charles 1983). The figures in the table are based on a survey conducted in 1982, and it is evident that the majority of households contacted never obtained veterinary care for their farm animals. 
Table 3. Percent of households not getting veterinary care.

\begin{tabular}{lc}
\hline Pet and/or animal & $\begin{array}{c}\text { \% of households not } \\
\text { obtaining veterinary care }\end{array}$ \\
\hline household pets & 26.4 \\
dog & 52.8 \\
cat & 97.8 \\
fish & 92.5 \\
caged bird & 89.2 \\
rabbit & 93.4 \\
hamster & 79.8 \\
guinea pig & 97.4 \\
gerbil & 84.6 \\
other small rodent & 95.8 \\
reptile & 97.1 \\
other fowl & 97.5 \\
all others & 57.4 \\
horse & \\
agricultural animals & 52.7 \\
dairy cattle & 59.9 \\
beef cattle & 75.3 \\
swine & 72.1 \\
sheep & 97.5 \\
poultry & 76.9 \\
goat & Note: Percents based off of number of households which owned each type during year.
\end{tabular}

From: Charles, Charles and Associates, Inc: The Veterinary Services Market Study prepared for the American Veterinary Medical Association, July 1983.

\section{Alternatives and Economics}

A comprehensive treatment of alternatives to factory farming and the differences in production parameters, health maintenance expenditures, and cost-benefit ratios is beyond the scope of this paper. Suffice it to say at this time, alternatives are, fortunately, being developed and tested. The alternatives presented below do attempt to meet at least some of the following basic rights or needs that must be met by animal husbandry systems (Carpenter 1980): 1) freedom to perform natural physical movement; 2) association with other animals, where appropriate, of their own kind; 3) facilities for comfort activities, e.g., rest, sleep, and body care; 4) provision of food and water to maintain full health; 5) ability to perform daily routines of natural activities; 6) opportunity for the activities of exploration and play, especially for young animals; and 7) satisfaction of minimal spatial and territorial requirements, including a visual field of "personal" space. Deviations from these principles should be avoided as far as possible, but where such deviations are absolutely unavoidable, efforts should be made to compensate the animal environmentally (Carpenter 1980). 
The fact that high-technology swine units are expensive to build and maintain (and often do not meet production expectations) has been acknowledged by the pork industry (Vansickle 1984). Such considerations, coupled with welfare concerns, have prompted alternatives research and implementation. A "Family System" for hogs that endeavors to show how pig housing conditions can be designed according to basic ethological requirements is being developed (Stolba 1982; Wood-Gush 1985/86). Other alternatives to the narrow crates include A-frame huts on pasture (Hohmann 1985), and roomy $(5 \times 7$ feet), tilted indoor crates which allow both sow movement and piglet protection (McClinton 1985). A turn-around gestation crate has been designed (McFarlane and Curtis 1983) which may be used by producers interested in offering their sows more diversity in and control over their environment.

An aviary system for laying hens has been developed in Switzerland (Fölsch et al. 1983) and is reported to be comparable in productivity and economics to the deep litter and cage systems. Mason (1985) notes that a 1978 study by the Swiss Centre for Poultry collected data on the laying performance of 65,000 hens in 38 Swiss flocks (two-fifths on litter, remainder in cages) and there were no differences in laying performance between the two systems.

The standard economic arguments for factory farming are rapidly becoming passè in light of the farm economic crisis, consumer health risks due to residual chemicals and drugs, pollution, and depletion of soil and water resources. To quote Mason (1985):

...the financial benefits of factory farming are exaggerated, and furthermore, that they produce unhealthy animals and poor-quality products: to offset these effects factory farmers must employ an arsenal of antibiotics, hormones, drugs, chemical additives, colouring agents and other substances that may threaten human health. When one considers the potential magnitude of these health problems and the social cost of dealing with them, the food produced by factory methods may well be too expensive-regardless of its price at the market.

\section{Endnotes}

1 Paper presented at the national conference, "Animals and Humans: Ethical Perspectives," Moorhead State University, Moorhead, MN, April 21-23, 1986

${ }^{2}$ Research Associate, The Institute for the Study of Animal Problems, $2100 \mathrm{~L} \mathrm{St,} \mathrm{NW,} \mathrm{Washington,}$ DC 20037.

${ }^{3}$ Scientific Director, The Humane Society of the United States, and Director, The Institute for the Study of Animal Problems, 2100 L. St, NW, Washington, DC 20037.

${ }^{4}$ The fact that we present in-depth consideration of these two species is reflective solely of a limitation of space, and in no way implies that laying hens and brood sows are the only food animals kept in deprivational systems detrimental to their physical and psychological well-being. Indeed, the welfare of crated veal calves is of major concern, requiring urgent attention from animal scientists, animal welfarists, and the public alike. It is ethically unconscionable to continue to maintain veal calves in crates for the reasons of tradition and "psychology" (i.e., consumers expect veal to be white); the refinement of alternative systems make it unnecessary as well. 
Recent scientific studies document that the crate system is deleterious in terms of health, behavior, and production (see Friend et al. 1985; Fox 1984; Sambraus 1980, 1985; Saville and Webster 1981; Dantzer et al. 1983; and Webster 1986). Mason (1985) also reports that $40 \%$ of the members of the National Association of Veal Producers in Great Britain have adopted loose housing in groups for economic reasons; housing costs are halved, calves are healthier, and veterinary bills are reduced by $65 \%$.

\section{References}

Agscene. 1985. The big sell-out. 81: 6-7.

-. 1986. The wrong directive. 83: 4

Allen, J and Perry, GC. 1975. Feather-pecking and cannibalism in a caged layer flock. Brit. Poult. Sci. 16: 441-52.

Allman, WF. 1984. Drugs in feed: Fatter cattle, fitter bacteria. Science 84. 5(10): 16.

Bareham, JR. 1975. Research in farm animal behaviour. Brit. Vet. J. 131: 272-83.

Barnett, IL, Winfield, CG, Cronin, GM, Hemsworth, PH and Dewar, AM. 1985. The effect of individual and group housing on behavioural and physiological responses related to the welfare of pregnant pigs. Appl. Anim. Bebav. Sci. 14: 149-61.

Becker, BA, Ford, JJ, Christenson, RK, Manak, RC, Hahn, GL and DeShazer, JA. 1985. Cortisol response of gilts in tether stalls. J. Anim. Sci. 60(1): 264-70.

Bogner, H, Peschke, W, Sed, V and Popp, K. 1979. Berliner und Münchener Tieräztliche Wochenschrift. 92: 340.

Carpenter, E. 1980. Animals and Etbics. London: Watkins.

Chaboussou, F. 1980. Les Plants Malades des Pesticides: Bases Nouvelle d'une Prevention Contre Maladies et Parasites. Paris: Deband.

Charles, Charles and Associates, Inc. 1983. The Veterinary Services Market Study. Prepared for the American Veterinary Medical Association, July 1983.

Clark, S, Rylander, R and Larsson, L. 1983. Airborne bacteria, endotoxin and fungi dust in poultry and swine confinement builidings. Am. Ind. Hyg. Assoc. 44(7): 537-41.

Cook, RJ. 1986. Interrelationships of plant health and the sustainability of agriculture, with special reference to plant diseases. Am. J. Alt. Agric. 1(1): 19-25.

Craig, JV and Adams, AW. 1984. Behaviour and well-being of hens (Gallus Domesticus) in alternative housing environments. WSPA J. 40(3): 221-40.

Cronin, GM. 1985. The Development and Significance of Abnormal Stereotyped Bebaviours in Tethered Sows. Doctoral Thesis: Agricultural University of Wageningen. 1985.

Dantzer, R. and Mormède, P. 1981. Can physiological criteria be used to assess welfare in pigs? In: Sybesma, w. ed. The Welfare of Pigs. London: Martinus Nijhoff.

-. 1983. J. Anim. Sci. 57: 6-18.

Dantzer, R, Mormède, P, Bluthe, RM and Soissons, J. 1983. The effects of different housing conditions on behavioural and adrenocortical reactions in veal calves. Reprod. Nutr. Develop. 23(3): 501-8.

Dixon, B. 1986. Overdosing on wonder drugs. Science 86. May. 7(4): 40-44.

Donham, KJ, Zavala, DC and Merchant, JA. 1984. Respiratory symptoms and lung function among workers in swine confinement buildings: A cross-sectional epidemiological study. Arch. Env. Health. 39(2): 96-100.

Doyle, J. 1985. The Altered Harvest. New York: Viking Press.

Duncan, IJ and Hughes, BO. 1974. Some emotional factors influencing feather-pecking in growing birds. Brit. Vet. J. 129: 503-4.

Duncan, XJ and Wood-Gush, DG. 1972. Thwarting of feeding behaviour in the domestic fowl. Anim. Behav. 20: 444-51.

Ekesbo, I. 1981. Some aspects of sow health and housing. In: Sybesma, W. ed. The Welfare of Pigs. London: Martinus Nijhoff 
Ewbank, R. 1969a. Social behaviour and intensive animal production. Vet Rec. 85: 183-86. -. 1969b. Behavioural implications of intensive animal husbandry. Outlook Agric. 6: 41-46

Ferguson, W. 1968. Abnormal behaviour in poultry. In: Fox, MW. ed. Abnormal Bebaviour in Animals. Philadephia: Saunders.

Fölsch, DW, Dolf, C, Ehrbar, H, Bleuler, T and Teigeler, H. 1983. Ethologic and economic examination of aviary housing for commercial laying flocks. Int. J. Stud. Anim. Probs. 4(4):330-5.

Fox, MW. 1983. Animal welfare and the dairy industry. J. Dairy Sci. 66: 2221-5.

-. 1984. Farm Animals: Husbandry, Bebavior, and Veterinary Practice. Baltimore, MD: University Park Press.

-. 1985. Philosophy and ethics in ethology. In: Fraser, AF. ed. Ethology of Farm Animals. World Animal Science Series. A. No. 5. Amsterdam: Elsevier.

Fraser, AF. 1975. Farm Animal Behaviour. London: Bailliere Tindall.

Fraser, D. 1974. Behavior at three weeks. Pig Farming Suppl. Oct.: 61, 63, 71

Friend, TH, Dellmeier, GR and Gbur, EE. 1985. Comparison of four methods of calf confinement. I. Physiology. J. Anim. Sci. 60(5): 1095-1101.

Gross, WB. 1976. Plasma steroid tendency, sound environment and Eimeria necatrix infection. Brit. Poul. Sci. 55: 1508-12.

Gross, WB and Siegel, PB. 1982. Socialization as a factor in resistance to infection, feed efficiency and response to antigen in chickens. Am. J. Vet. Res. 43(11): 2010-12.

Gustafsson, B. 1983. Effects of sow housing systems in practical pig production. Trans. ASAE. 1181-93.

Hall, WF 1984. Stress and the farrowing sow. Hog Farm Manage. July: 13-14.

Harvey, G. 1983. Poor cow. New Scientist. Sept. 29: 940-43.

Hodges, RD and Scofield, AM. 1983. Effect of agricultural practices on the health of plants and animals produced: A review. In: Lockeretz, W. ed. Environmentally Sound Agriculture. New York: Praeger.

Hohmann, K. 1985. Extensive A-frames. Hog Farm Manage. July: 26-27.

Holmberg, S, Osterholm, M, Senger, K and Cohen, M. 1984. Drug-resistant Salmonella from animals fed antimicrobials. New. Eng. J. Med. 311(1): 617-22.

Houston Post. 1984. Health watch: Ailing farmers. Dec. 28.

Huber, HU, Fölsch, DW and Stähl, U. 1985. Influence of various nesting materials on nest site selection of the domestic hen. Brit. Poult. Sci. 26: 367-73.

Hughes, BO. 1983. Conventional and shallow cages: A summary of research from welfare and production aspects. WSPA $J$. 39(3): 218-28.

Kiley-Worthington, M. 1977. Behavioural Problems in Farm Animals. London: Oriel

Kilgour, R. 1985. Management of behaviour. In: Fraser, AF, ed. Etbology of Farm Animals. World Animal Science Series. A. No. 5. Amsterdam: Elsevier

Levy, DM. 1944. On the problem of movement restraint, ticks, stereotyped movements, hyperactivity. Am. J. Ortbopsychiatr. 14: 644-71.

Long, C. 1985. Dirty dozen. Agscene. Nov./Dec. 81: 13

Mason, J. 1985. Is factory farming really cheaper? New Scientist. 28 March (1449): 12-15.

McBride, G. 1966. The conflict of crowding. Discovery. 27: 16-19.

-. 1968. Social organization and stress in animal management. Proc. Ecol. Soc. Austral. 3: 133-38

McClinton, D. 1985. "Happier" animals, higher profits. The Furrow. July/Aug. 8-11.

McFarlane, JM and Curtis, SE. 1983. Bebavior of mated gilts in a tum-around gestation crate. Cooperative Extension Report, 1983-16. Univ. of Illinois at Urbana-Champaign.

Mills, AD and Wood-Gush, DG. 1985. Pre-laying behaviour in battery cages. Br. Poult. Sci. 26: 247-52.

Mills, AD, Wood-Gush, DG and Hughes, BO. 1985. Genetic analysis of strain differences in pre-laying behaviour in battery cages. Br. Poulty. Sci. 26: 187-97. 
Moss, BW. 1981. The development of a blood profile for stress assessment. In: Sybesma, W. ed. The Welfare of Pigs. London: Martinus Nijhoff.

New Scientist. 1986. Swiss chickens choose home comforts. 109(1493): 33.

O'Brien, T, Hopkins, J, Gilleece, E, Medeiros, A, Kent, R, Blackwood, B, Holmes, M, Reardon, J, Vergeront, J, Schell, W, Christenson, E, Bissett, $M$ and Morse, E. 1982. Molecular epidemiology of antibiotic resistance in Salmonella from animals and human beings in the United States New Eng. J. Med. 301(1): 1-6.

OTA (Office of Technology Assessment). 1985 Technology, Public Policy, and the Changing Structure of American Agriculture: A Special Report for the 1985 Farm Bill. Washington, DC: U.S. Congress.

Peterson, C. 1986. Food supply called unprotected: FDA accused of allowing improper use drug use in farm animals. Washington Post. Jan. 13: A5.

Pig America. 1984. Universities dispute value of gestation stalls. March: 16-17.

Rhein, RJ and Siwolop, S. 1986. Drugs in animal feed: Now the FDA is drawing heavy fire. Business Wk. Feb. 3: 70F.

Rushen, JP. 1985. Stereotypies, aggression and the feeding schedules of tethered sows. Appl. Anim. Beh. Sci. 14: 137-47.

Sambraus, HH. 1980. Humane considerations in calf rearing. Anim. Reg. Stud. 3: 19-22.

- 1985. Mouth-based anomalous syndromes. In: Fraser, AF. ed. Ethology of Farm Animals. World Animal Science Series. A. No. 5. Amsterdam: Elsevier.

Saville, C and Webster, JF. 1981. Basic necessities for ensuring the welfare of veal calves in various housing systems. Appl. Anim. Ethol. 1: 382-83.

Siegel, HS. 1985. Effects of intensive production methods on livestock health. Agro-Ecosystems. 8: $215-30$.

Somogyi, A. 1985. Drug residues. World Health. July: 26.

Stolba, A. 1982. A family system of pig housing. Proc. Symp. Alternatives to Intensive Husbandry Systems. Potters Bar, England: Universities Federation for Animal Welfare.

Tauson, R 1984. Effects of a perch in conventional cages for laying hens. Acta Agric. Scanda. 34: 193-209.

USDA (United States Department of Agriculture). 1983. Agricultural Statistics. Washington, DC: U.S. Govt. Print. Off.

Van denBergh, SG. 1976. Abnormal lipid metabolism and production diseases. In: Proc. of the Third Intermatl. Conf. on Production Diseases in Farm Animals. Wageningen, The Netherlands. Sept. 13-16, 1976.

Vansickle, J. 1984. High-tech units swallow profits. Natl. Hog Farmer. March 15: 80,82.

Vestergaard, K. 1981. Influences of fixation on the behaviour of sows. In: Sybesma, w. ed. The Welfare of Pigs. London: Martinus Nijhoff.

-. 1983/84. Are tethered sows stressed: A behavioural comparison of tethered and loose sows. Appl. Anim. Ethol. (Abstr.) 11: 81-82.

Webster, J. 1986. Health and welfare of animals in modern husbandry systems-Dairy cattle. In Practice. May.: 85-89.

Wood-Gush, DG. 1973. Animal welfare in modern agriculture. Brit. Vet. J. 129: 67-74.

-. 1985/86. The attainment of humane housing for farm livestock. In: Fox, MW and Mickley, LD. eds. Advances in Animal Welfare Science 1985/86. Washington, DC and Dordrecht, The Netherlands: The Humane Society of the United States and Martinus Nijhoff, respectively.

Wood-Gush, DG, Duncan, IJ and Fraser, AF. 1975. Social stress and welfare problems in agricultural animals. In: Hafez, ES. ed. The Behaniour of Domestic Animals. London: Bailliere Tindall

WSPA (World Society for the Protection of Animals). 1985. Tethering of Dry Sows. by the Scientific Advisory Panel. May. 